Studia Anglica Posnaniensia 45/2, 2009

doi: 10.2478/v10121-009-0014-5

\title{
MIDDLE ENGLISH MEDICAL RECIPES: A METADISCURSIVE APPROACH $^{1}$
}

\author{
ELENA QUINTANA-TOLEDO
}

University of Las Palmas de Gran Canaria, Spain

\begin{abstract}
This paper seeks to explore Middle English medical recipes from a metadiscursive perspective. This study will draw on Hyland's (2005) metadiscourse model where code glosses, endophoric markers, evidentials, frame markers and transition markers are included in the interactive dimension, and attitude markers, boosters, engagement markers, hedges and self mention are to be found within interactional metadiscourse. I shall apply this framework for the identification and analysis of data in a corpus which comprises a selection of recipes taken from both Middle English Medical Texts (Taavitsainen - Pahta - Mäkinen 2005) and The corpus of early English recipes. The metadiscursive approach to the study of medical recipes will allow us to establish links between authors, texts and audience of the recipe genre and, consequently, to affirm their status as products of social engagement.
\end{abstract}

\section{Introduction}

Metadiscourse is an umbrella term for a wide array of disparate linguistic elements whose function is that of relating all the entities involved in a communicative exchange, that is, text producers, text receivers and texts themselves. Metadiscursive analysis, then, will account for aspects such as author presence, audience awareness and text composition, among others. In this framework, communication is understood as social engagement: personalities, attitudes and assumptions of those communicating are linguistically codified in texts and they determine both text production and text reception.

Ms Elena Quintana-Toledo collaborates in the research project "Evidencialidad en un corpus multidisciplinar de artículos científico-técnicos en lengua inglesa”, grant FFI200910801 (FEDER, Spanish Ministry for Science and Innovation). This grant is hereby gratefully acknowledged. 
This paper aims at exploring the occurrence of metadiscursive features in Middle English medical recipes so as to ascertain to what extent they are products of social engagement. In order to do so, I shall follow Hyland's (2005) categorisation of metadiscourse since, to date, it offers the most comprehensive classification of metadiscursive features which, in turn, provides researchers with an efficient tool for their identification. The analysis of metadiscursive strategies will ultimately allow us to deepen into the characterisation of the relationships between producers and audience of the Middle English recipe genre.

Recently, there has been a growing interest in analysing the role of metadiscourse in several genres such as research papers (Kuo 1999; Martín-Martín 2008), PhD theses (Bunton 1999), opinion columns (Dafouz-Milne 2008), introductory textbooks (Hyland 1999), slogans and headlines (Fuertes-Olivera et al. 2001), among others. From a diachronic perspective, medical texts have been specifically scrutinised in the studies conducted by Taavitsainen (1994, 1999, 2001a) where the focus has been on emotionality, involvement and writer/reader relationships as codified through personal and impersonal commentaries as well as on evidentials. In this article, however, I shall try to characterise Middle English medical recipes from a metadiscursive standpoint in a more unified manner by drawing on Hyland's theoretical proposal.

This said, the paper is structured as follows: the next section focuses on the description of the corpus of study and its characterisation in terms of genre and text type features. The third section contains a brief overview of the concept of metadiscourse and the presentation of Hyland's taxonomy. Section 4 holds the analysis of the texts and their pragmatic interpretation. Section 5 presents the conclusions drawn from the present study.

\section{Corpus of study}

The texts surveyed here form a corpus of 50,000 words approximately. They have been taken from both Middle English medical texts (MEMT) (Taavitsainen - Pahta - Mäkinen 2005) and The corpus of early English recipes (CoER). The assessment of metadiscursive strategies has been carried out by using computing tools for their initial identification together with manual analyses for their pragmatic interpretation. The rest of this section is devoted to a brief description of $M E M T$ and $C o E R$ and, specifically, of the sampled material in terms of genre and text type features.

$M E M T$ and CoER are electronic compilations of medical texts. The former, developed in the English Department of the University of Helsinki, contains texts from 1375 to 1500 which have been organised according to the three traditions of medical writing described by Voigts (1982), that is, (i) surgical texts, (ii) specialised texts, and (iii) remedies and materia medica. The latter is a pro- 
ject still in progress in the University of Las Palmas de Gran Canaria which is being carried out by the TeLL (Tecnologías Emergentes aplicadas a la Lengua y a la Literatura) Research Group in collaboration with members of CeTIC (Centro Tecnológico para la Innovación en Comunicaciones). The team pursues a twofold aim: firstly, the compilation of recipe texts written in English and dating from 1375 to 1750 , and secondly, the design and implementation of an information retrieval tool which allows researchers to work with the texts.

For this study, I have made a random selection of some of the remedy books comprised under the third category in MEMT to which I have added another one whose complete edition can be found in the medieval part of $C o E R$, even though an excerpt of it is also present in MEMT. Table 1 shows the list of remedy books from which the Middle English medical recipes under scrutiny have been excerpted:

Table 1. List of remedy books used in the analysis

\begin{tabular}{|c|c|c|c|}
\hline Abbreviation & Name in $M E M T$ & Source & Evk no. \\
\hline KMT & $\begin{array}{c}\text { Killeen Medical } \\
\text { Texts }\end{array}$ & Trinity College Dublin 158 & 2219.00 \\
\hline $\mathrm{RR}$ & $\begin{array}{l}\text { Rupescissa, } \\
\text { Remedies }\end{array}$ & $\begin{array}{l}\text { Glasgow University Library } \\
\text { Ferguson } 205\end{array}$ & 806.00 \\
\hline R1 & Recipes 1 & Olim Phillipps 335 & 4936.00 \\
\hline $\mathrm{R} 2$ & Recipes 2 & $\begin{array}{l}\text { British Library Additional } \\
33996\end{array}$ & 2474.00 \\
\hline R3 & Recipes 3 & $\begin{array}{l}\text { Glasgow University Library } \\
\text { Hunter } 185\end{array}$ & 4988.00 \\
\hline
\end{tabular}

The material contained in these remedy books belongs to the Middle English period and, in particular, they contain fourteenth and fifteenth century medical recipes. Languages other than English such as Latin and French are used at times, but those fragments have not been taken into consideration in the present analysis in order to achieve more precise results for the English language. It should be noted that R3 is an abbreviation derived from the name given in MEMT to an excerpt of the remedy book contained in G.U.L. Hunter 185. Nevertheless, the recipes analysed in this study do not only include those in Recipes 3 as they are found in $M E M T$, but also the rest of the remedies as they appear in the whole edition of the manuscript, which as such has been included in CoER.

Any text can be assessed in terms of external and internal criteria. External criteria are related to the relationships that can be established between a specific text and its purpose in a particular sociohistorical context, while internal criteria are connected to the internal linguistic features of a given text. These standards 
for the classification of texts correspond to the concepts of genre and text type respectively, both of which have been successfully applied to the study of recipe texts from the Middle English period (Carroll 1999; Taavitsainen 2001b; Alonso-Almeida 2008).

Genre assessment is primarily done on the basis of the extralinguistic parameters which govern any communicative situation irrespective of its being written or spoken. Systemic Functional Linguistics has provided researchers in the field with a solid theoretical framework in order to do so, above all, with respect to the clarification of the terminology. Martin (1984: 25) defines genre as "a staged, goal-oriented, purposeful activity in which speakers engage as members of our culture". Hasan's (1985: 63-63) and Eggins's (1994: 41) work on the notion of stage resulted in the association of the basic organisation of genres to the labels "generic structure potential" and "actual generic structure": all genres have a certain ideal structure which includes all the possible stages they can have; this they call "generic structure potential". These stages may or may not be present in an actual instance of a genre, the resulting structure being what they call "actual generic structure".

Within the medical register, the recipe genre is intended to provide its audience with instructions so as to prepare efficient medical products. It normally consists of a title, a list of the ingredients, some explanations as regards their preparation and application, and an utterance which points at the efficacy. The following example illustrates the structure of the recipe genre:

1) (Title) For the goute festred. (Ingredients) Tak auaunce, archangel, hayhoue, beteyne, verueyne, ana. (Preparation) Tak most of auaunce \& boyle hem in wyn. (Application) Let pe seke drynke perof ferst \& last (Efficacy) $\&$ he schal be hol.

The recipe in 1 presents the following actual generic structure: the first stage is the title, where the author indicates what the remedy is for. It is followed by the list of ingredients which are needed to make it, and by the explanation of the procedure of preparation. Then, the application section indicates how to give the resulting medicine to the patient. Finally, the efficacy of the medicine is asserted by a description of the expected results after its application, that is, that the patient will recover.

In relation to text types, these apply to the specific, internal linguistic features of texts. Werlich (1976) proposed a taxonomy according to the linguistic variables which can be found in them: descriptive, narrative, expository, argumentative and instructive. Let us consider the sample above again to describe recipes in terms of text type characteristics: imperatives in (1) such as take, boyle and let are indicators of an instructive text type. Further grammatical characterisation of this 
example includes the following: (i) constructions with for followed by a noun phrase in the title section; (ii) imperative verbal forms and weight references in the ingredient section; (iii) imperatives connected by and conjunctions in the preparation section; (iv) verbs with CoERcive meaning (Alonso-Almeida 2008: 176) and time expressions in the application section; and finally, (v) and conjunctions indicating result, third person singular pronouns and verbal forms with future meaning marked by schal in the efficacy section.

From a lexical perspective, stages in the recipe genre in example (1) can be characterised as follows: (i) nouns which refer to illnesses appear in the title; (ii) the ingredient section contains plant names and, in general, any other substance which might be used in the preparation of the remedies; (iii) cooking verbs and ingredients are found in the preparation section; (iv) expressions referring to the patient and numerals indicating duration or specific points in time appear in the application section; and (v) the efficacy section contains words related to the lexical field of recovery from an illness.

\section{The concept of metadiscourse}

Metadiscourse has always been a fuzzy concept and, as Swales (1990: 188) notes, "although the concept of metadiscourse is easy to accept in principle, it is much more difficult to establish its boundaries". Furthermore, the number of resources that can signal metadiscursive relationships is potentially large since the presence of both text producers and text receivers can be codified through diverse linguistic items in a given text. Apart from this, discourse organisational patterns, though somewhat neutralised by the grammar of a language, are ultimately specific to each individual and so this adds a layer of complexity to the issue. However, many scholars have agreed on its importance as a pragmatic concept, which has led to several definitions and taxonomies of metadiscourse.

Williams (1981: 211-212) defined metadiscourse as "writing about writing, whatever does not refer to the subject matter being addressed", first suggesting a distinction between two levels of meaning, namely, the discursive level and the metadiscursive level. The former supplies the propositional content of a text while the latter provides the reader with material for assisting him/her in the interpretation process. Vande Kopple $(1985,2002)$ and others like Crismore and Farnsworth (1989) adopted and developed this view drawing on concepts of Systemic Functional Linguistics, in particular, on the Hallidayan metafunctions which are simultaneously realised by language: ideational, interpersonal and textual. The first one corresponds to the primary, discursive level and so, to the propositional or representational material. The other two are attached to the secondary, metadiscursive level: elements within interpersonal metadiscourse help writers express their personalities and attitudes towards the ideational con- 
tent. They also help readers grasp the nature of the relationship writers intend to establish with them through the text. As for the elements within textual metadiscourse, they help writers build their texts as a cohesive and coherent whole where each individual item makes sense in conjunction with the others.

Vande Kopple (1985: 83-85) went on categorising metadiscourse and he proposed a classification system containing seven types, i.e. (i) text connectives, (ii) code glosses, (iii) validity markers and (iv) narrators, which operate on textual metadiscourse, and (v) illocution markers, (vi) attitude markers and (vii) commentaries, on interpersonal metadiscourse. His writings on metadiscourse were strongly influenced by truth conditional semantics as he (Vande Kopple 1985: 85) specifically argued that metadiscursive meanings "do not expand the propositional information of a text. They do not make claims about states of affairs in the world that can be either true or false". His views on metadiscourse seem to suggest that it can be easily isolated from ordinary discourse and analysed separately.

Nevertheless, some scholars have realised that metadiscourse is not a discrete feature but an integral part of texts which should be carefully examined so as not to miss an important aspect of their pragmatic interpretation. Metadiscursive features do not simply facilitate the interpretation of the propositional content, in which case they could be overlooked and texts would remain the same. It is essential to achieve their full understanding, including the pragmatic dimension, if only because texts cannot remain unaffected if one were able to remove all metadiscursive items. The approach to metadiscursive studies, consequently, should be more holistic and so Infantidou (2005) offers an interesting solution for this problem by integrating both discourse and metadiscourse within the framework of relevance theory.

Hyland's contribution to metadiscursive studies is worth mentioning at this point since he offers a revision of the concept and of earlier classifications of metadiscursive features. He (Hyland 2005: 37) defines metadiscourse as "the cover term for the self-reflective expressions used to negotiate interactional meanings in a text, assisting the writer (or speaker) to express a viewpoint and engage with readers as members of a particular community". Taking Thompson's and Thetela's (1995) distinction between interactive and interactional resources as a starting point, Hyland (2005: 48-54) proposes a metadiscourse model based on a functional approach.

Hyland's metadiscourse model distinguishes between interactive and interactional resources. Interactive markers are discourse organisational devices whose use depends, among other things, on the writer's knowledge of his target audience in relation to their comprehension capabilities and need for interpretative guidance. Interactive resources include transition markers, frame markers, endophoric markers, evidentials and code glosses. As regards interactional fea- 
tures, these are those items which indicate author presence and, specifically, his attitude towards informational content and readers themselves. They also show audience awareness and reader involvement, and they are hedges, boosters, attitude markers, self mention and engagement markers. I shall use this taxonomy for the identification and analysis of metadiscourse in Middle English medical recipes in the following section.

\section{Analysis of metadiscursive features in Middle English medical recipes}

This section deals with the analysis of metadiscursive features in Middle English medical recipes. Following Hyland's classification of metadiscourse into two categories, I shall first focus on those elements with an interactive dimension and later on those which indicate interactional metadiscourse. I will perform both quantitative and qualitative analyses for which I have excluded passages which are not written in English.

\subsection{Interactive metadiscursive items}

Interactive metadiscursive resources include the following: code glosses, endophoric markers, evidentials, frame markers and transition markers. The graph below shows their distribution in the corpus analysed:

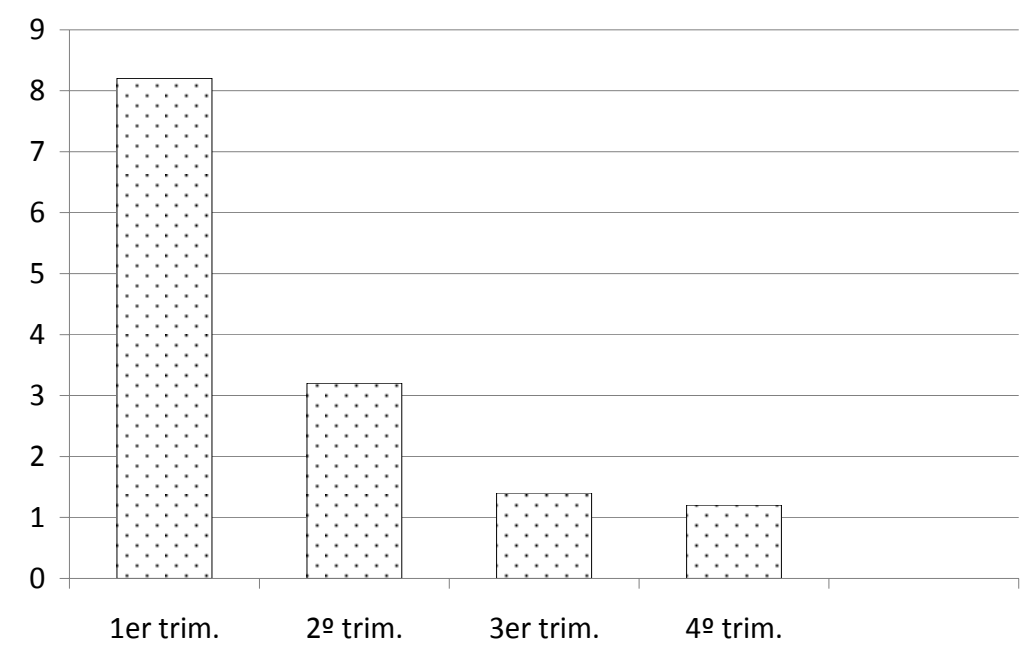

Figure 1. Distribution of interactive resources 
As shown in Figure 1, writers of the recipe genre make substantially more use of transition markers than of any of the other resources. This may be due to the social purpose of the genre in question which is to provide the readers with detailed instructions for the preparation of medical remedies in which case the relationships between main clauses must be unambiguous. Writers make an overwhelming employment of this interactive resource, specifically, in $86 \%$ of the cases, while endophoric markers, frame markers, code glosses and evidentials show much lower frequencies: $5 \%, 4 \%, 3 \%$ and $2 \%$, respectively. I now turn to their individual analysis.

\subsubsection{Transition markers}

Transition markers are conjunctions which indicate additive, resultive and contrastive relations between ideas. Hyland (2005: 50) points out that "it is unimportant whether items here contribute to syntactic coordination or subordination, but to count as metadiscourse they must perform a role internal to the discourse rather than the outside world, helping the reader interpret links between ideas". And is the most frequent transition marker in the corpus:

2) For hym that is in the jaunes: tak wormot and seth hit lange in water, and wasch the seke man with that water thrys ryght wele, and gyf him to drynk yvore schavyn smal in wyne (R1).

Contrary to what is expected from its logical operator counterpart, its meaning cannot be said to be truth conditional, but contextually determined. In this sense, Alonso-Almeida (2008) has performed an analysis of the different meanings this conjunction may have in Middle English medical recipes from a relevance theoretic perspective. He found out that a whole range of values can be attached to and, namely, time, time-purpose, purpose, result, additive, adversative and conditional. In the case of example (2), and indicates (i) time-purpose, i.e. tak wormot and seth it lange in water, (ii) purpose, i.e. and wasch the seke man with that water thrys ryght wele, and (iii) time, i.e. and gyf him to drynk yvore schavyn smal in wyne.

\subsubsection{Endophoric markers}

Endophoric markers are linguistic devices by means of which writers refer to other parts of the text. They help readers in the recovery of intended meanings by moving back and forward within stretches of discourse. Let us consider the

recipe texts below: 
3) Another drynk to wounde: tak confery, marigolde, matfelon, mylfoyle, avance, cerfoyle, herbe Robert, ambrose, maroile, pellwet, rede-dok, polipody, the qwite rote of walwort, baywort, and celidoyne, of ilkane illike mykell, and of madre hafe the wegh of al thir othir herbes byfor nevend, seth tham in ale or in wyne, and drynk tham morn and even, and do als hit says before (R1).

4) take and sepe verueyne, and betonye, and wermod and per wyp wasche pe seke heued, $\& \sim$ panne make a plasture aboue on pe moolde on pis manere: Take pe same erbys, when pey beon sodyn, and wrynge hem and grynde hem smale in a morter, and tempre hem wyp pe same licour azeyne, $\& \sim$ do per to wheton branne, to holde in pe licour, and make a garlande of akerchef, and bynde pe seke heued, and ley pe plasture on pe molde wyb ynne pe garlaunde, as hoot as pe seke may suffre, and bynde pe hed wyp a volyper, and sette a kappe aboue, and pys do bote pre dayes, and pe seke shal be hool on warantyse (R2).

(3) and (4) illustrate the use of endophoric markers, (3) with anaphoric reference and (4) with cataphoric reference. Byfor nevend and on pis manere are primarily cohesive devices by means of which some sort of continuity of reference is established between the information being pointed out and the endophoric devices themselves (Halliday - Hasan 1976: 31). Their function is mainly explanatory as they point to key parts of the text for the reader to grasp the meaning of the propositional material. In doing so, they provide the reader with immediate access to previously mentioned contexts or to others which are to come. Certain specific uses have been observed, though: anaphoric devices often make reference to ingredients, either individually or in group, and cataphoric devices are not normally used to refer to single noun phrases, but to whole sentences where the procedure of preparation is stated.

\subsubsection{Frame markers}

Frame markers are linguistic items which indicate textual boundaries and so, they serve the purpose of offering a frame for certain parts of discourse (Hyland 2005: 51). They can be grouped into different categories according to their specific functions:

5) Yn this chapitre we clepe paym dede in whoom we stonde in doute of paire life and pe whiche been so nigh deeth pat phisike and leches forsaken thaym for pay been destitute of th'actes of lyfe (RR). 
6) Now for to make a purgacioun. Tak laureole \& make powdere perof. Tempre hit with hony $\&$ of eyper jlyke muche. Bat schal delyuere hym (R3).

7) Fro the bigynnyng of pe worlde into pis day, alle philosophres han laborid with grete swette and besynes aboute medicines laxatifz for iij thingz. The furst is pat by laxatifz, kinde and vertue shal not awey. The $i j=d e=i s ~ p a t$ pay sle not. The $\mathrm{iij}=\mathrm{de}=\mathrm{is}$ whenne neede, spedefully and effectually withoute any peril to wirke in ferre parties of pe body and mightily to bringe corrupte humours fro pens (RR).

(5), (6) and (7) epitomise the employment of this interactive feature of metadiscourse in the recipe genre. In general, they are used to clarify the schematic structure of the recipes and this is really helpful in the case of remedy books since they contain large numbers of recipes with different lengths. In particular, the frame markers used in these examples fulfil different functions. For instance, $y n$ this chapitre in (5) is a device which allows the writer to state his goal, and so, where he wants to get in this part of the recipe guiding the audience in the understanding of his aim. Now in (6) marks a shift in the topic which has been dealt with up to that part of the text and introduces a new one. And finally, in (7) the writer employs the furst ... the $i j=d e=\ldots$ the $i i j=d e=\ldots$ to sequence a list of arguments in favour of laxative medicines.

\subsubsection{Code glosses}

Code glosses are linguistic items which provide the reader with additional information as a way of ensuring he is able to recover meanings of ideational material as intended to be conveyed by the writer. Recipes (9) and (10) contain instances of the use of this metadiscursive feature in the texts analysed:

8) For a sore pat watrep or prikkep be be boon. Tak alom roch \& sepe it in water til half be wasted. Wessch perwith pi sore ofte jnoz. Penne, tak brome blosmes, herbe benet (summe men callep it hemelok) \& tak plantayne \& may botere. Grynde pese foure togedre smal \& do hem in a vessel \& let ly so iij dayes, or iiij, til it be hor. Panne put it into a panne, melte it $\&$ strayne it into a vessel. Let kele \& panne, after pi wasschyng with pyn alom water, ley on perof. It wol do awey al pe akyng, swellyng \& schabbes \& make feyre \& hool (R3).

9) Also an other for pe same. Tak pullyole de moyntayne, pat is to say, hillwort or brodewort a good handful, wessch hit clene \& schere hit smal. Do it in a mortere \& grynde hit small. Do perto half an vnce of poudere of 
peper \& an vnce of poudere of comyn \& medle hem togedere haluendel be wasted. Do perto also a potel of good wyn \& penne seep it as it ys seyde tofore. Let pe pacient vse pis after mete \& not before, but ones after none $\&$ at eue last \& algate hoot. He schal be hool (R3).

These two recipes contain the most frequently found code glosses in medical texts. In general, code glosses indicate semantic relationships of elaboration as they are used to further specify or describe propositional material (Halliday 1985: 203). In the examples above, the semantic relationship of elaboration is made explicit by the use of punctuation marks, i.e. (summe men callep it hemelok), and by the conjunctive expression pat is to say. From a pragmatic perspective, they are indicators of the writer's a priori assumptions about the reader's knowledge on a particular subject. In the case of the recipe genre, code glosses appear to be specially connected with ingredients, above all plant names, where the writer chooses to offer alternatives in case he considers them to be problematic for his target audience. They often signal the writer's stance towards his readers and their use may result in patronising commentaries when read by an expert, and just the opposite if the writer expects too much knowledge on the part of the audience.

\subsubsection{Evidentials}

The term evidentiality is not a clear one, not even its scope in research. However, there are certain uses of the concept which aim at reducing complexity. In the broad sense, evidentiality refers to both the source of knowledge and the degree of certainty, while in the narrow sense it refers to the source of knowledge only. In this section, I will be using the concept in the broad sense where evidentials can be defined as "markers which qualify the reliability of information communicated in four primary ways. They specify the source of evidence on which statements are based, their degree of precision, their probability, and expectations concerning their probability" (Mithun 1986: 89).

In the recipes analysed, evidentials are the least frequent interactive resource, only occurring in $2 \%$ of the occasions as in the fragment below:

10) But among alle solempne medicines, high leches and cunnyng commenden aloe and praysin hit highly. For as pay veylen and seyen, hit hath leste power to lesse any vertue of kinde and causith ful lite hurtyng of kinde in a man. For hit wil rather cumforte pe membris as hit proueth wel and euidently by Johan Eheban of Mesue in his Boke of Simple Medicines (RR). 
It has been observed that the density of these expressions is higher in passages where the efficacy of the remedies is asserted. This is so because they are precisely summoned by the writer when he wants to support his positive recommendation of the medicine in which case he appeals to the words of other authorities on the subject. In the case of example (10), the writer's credibility when asserting the efficacy of the remedy is reinforced by making use of someone else's authority. Moreover, the writer's commitment to the truth of the proposition expressed achieves the highest degree as the evidential is included in a sequence made up by boosters like proueth, suggesting empirical testing, and euidently, appealing to sensory evidence.

\subsection{Interactional metadiscursive items}

Interactional metadiscursive resources comprise attitude markers, boosters, hedges, self mention and engagement markers. Their distribution in the corpus is summarised in Figure 2:

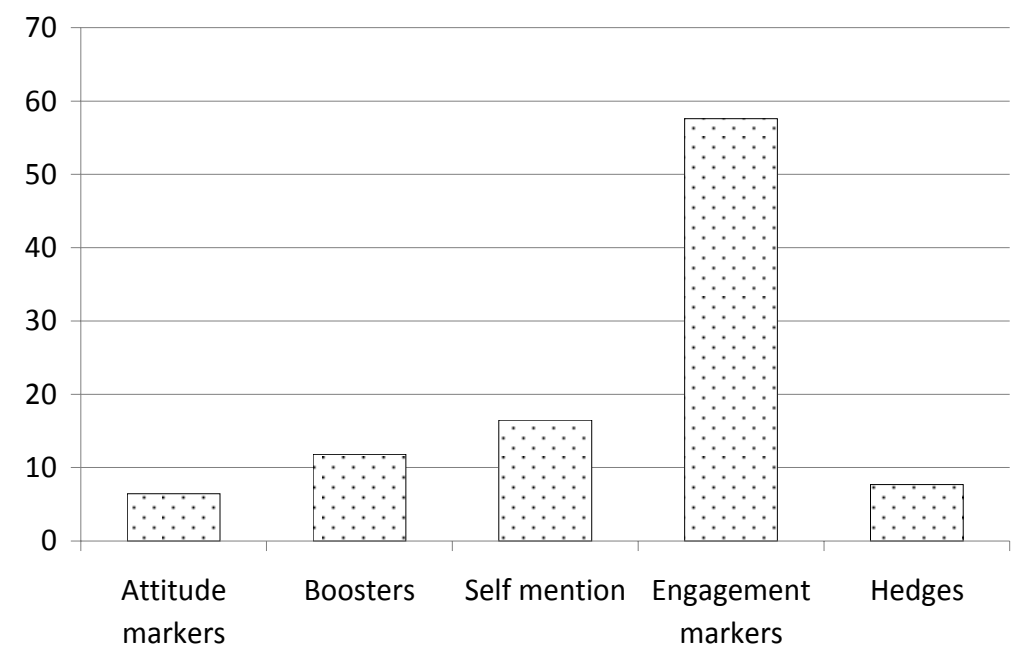

Figure 2. Distribution of interactional resources

Engagement markers present the highest frequency occurring in $58 \%$ of the cases, followed by self mention and boosters with percentages of 16 and 12 , respectively. Hedges and attitude markers occur less frequently, the former in $8 \%$ and the latter in $6 \%$ of the occasions. The remainder of the section is devoted to their analysis. 


\subsubsection{Attitude markers}

Attitude markers are devices which indicate the writer's stance towards his writing which, consequently, determines how his text is to be taken. This is mainly expressed through attitude verbs, sentence adverbs and adjectives. As shown by their frequency of occurrence, attitude markers are rare in the corpus and they tend to be adjectives and adverbs:

11) For wondys \& for sorys a gode medycin Take auaunce bogell pygel senegle $\&$ ach $\&$ erbe robrd veruayne erbe water waybrede daysye rybbe croppe of pe pe red worte crope of pe rede brere \& pe holyhoke \& stamp Ilkn by hem selfe (KMT).

12) Take watre of strowberies pe whiche is swete smylling frute and moyste; and pis watre in cure of lepre hath a heuenely vertue. And trowe wel pat quynte essence and strawbery watre togedre heleth the lepre wondrefully and mervailleusely (RR).

This interactional resource tends to occur in efficacy statements and so, can be understood as part of the formulaic language used to convey the positive outcome of the application of a remedy. There seems to be a logical connection between efficacy statements and attitude markers, especially in the case of the recipes analysed as this metadiscursive resource is mainly expressed through evaluative adjectives, i.e. gode, and adverbs, i.e. wondrefully and mervailleusely, all of which emphasise the writer's position in relation to the use of certain medical products, that position being one of conviction in its curative properties and so of recommendation for use. In other words, they express the author's appreciation (Koutsantoni 2004: 169) of a product as efficient for healing purposes and determine readers' guidance towards its understanding just in the same way.

\subsubsection{Boosters and hedges}

Boosters and hedges are items which can be said to stand at opposite ends in the continuum of the degree of commitment to textual information. They show the writer's position towards a particular list of alternatives or choices. On the one hand, boosters, also called emphatics, are elements by means of which the writer chooses one of the alternatives and dismisses the others. As such, they convey certainty (Hyland 2000: 179). Hedges, in contrast, sometimes referred to as downtoners or downgraders, are used by writers so as to leave the list of choices opened. Their use allows them to mitigate compromise by presenting information as opinions rather than as facts (Hyland 1998: 5). Their value is that of uncertainty. Let us consider the following fragments for illustration: 
13) Another for wynd and ventosite, that men callis collica passio, and this es wel proved: tak and make the a girdil of seel skyn, and whil thu weres hit a boute thi body thu sal noght have collicam passionem (R1).

14) For yf pe quynte essence of any laxatife thing be put in oure quynte essence spiritualy, hit suffrith noo maniere vomett ner braking to be ingendrid in pe stomake. For pe spirituale receipued shuld not be voyded, yit hit semeth possible pat pe humours pat been ingendrid in pe stomake shuld be voide by vometing. And many of pees medicines been venoym and hurten often tymes of paire owen kinde. But with quynte essence or aqua ardent, hit doeth not so for porough cumforte of quynte essence, hit is not hurte (RR).

(13) contains the booster proved by means of which the writer emphasises the force of the proposition "the remedy to be dealt with in the following lines has been proved". Proved serves the purpose of stating his attitude towards the efficacy of the remedy which is, again, one of conviction in its curative properties. From the point of view of the audience, proved tightens the alternatives, letting the readers derive from its use that this medicine is going to work for sure. In (14), two hedges have been combined in order to mitigate the writer's commitment to the textual information offered. The sequence contains the epistemic lexical verb semeth which provides evidentiary justification on the grounds of the writer's or someone else's sensory perception, mainly visual, and the epistemic adjective possible in order to further mitigate the already downtoned sequence by the employment of semeth, rendering the proposition in which they are inserted very vague. In so doing, the author reduces its likelihood. The writer's exact degree of commitment to this proposition can be hardly determined, even though it is not difficult to note that it is rather low. However, when compared to the one conveyed by proved, they clearly stand at the two extremes of the continuum.

\subsubsection{Self mention and engagement markers}

The realisations of self mention and engagement markers in my corpus are closely related to the speech roles identified by Halliday and Hasan (1976: 45), that is, addresser and addressee. These resources are primarily realised by the use of first and second person pronouns.

The first person singular pronoun is associated with authorial identity while its plural counterpart is connected to the concept of community. This is essential in the metadiscursive framework as it points at the idea of communication as always accounted for in terms of social contexts. Barton (1994: 57) defines community as "a group of people who have texts and practices in common... In fact, discourse community can refer to the people the text is aimed at; it can be 
the people who read a text; or it can refer to the people who participate in a set of discourse practices by both reading and writing". It is, then, always present in text production and reception and becomes explicitly represented through the use of personal pronouns. Fragments (15), (16) and (17) contain typical examples of self mention and engagement markers as found in the corpus:

15) Also, let pe seke wassche hys heued with pe liquor bat comep after \& make a plaster of pese herbes pat $\mathrm{j}$ schal nenme: Tak rewe, hey bone, beteyne, verueyne, myntes, hillwort, redfenel, wermot, sowthernewode, of eche an hanful. Wassch hem clene, schere hem, \& seep hem in an erpen pot in faire water (R3).

16) And among alle sikenesses, pe plage of lepre is moste cursid and moste lothesum to man and sumtyme harde to be curid and sumtyme impossible. For sumtyme hit cometh of pe sending of God as pe lepre was sente to pe Constantyne of Grece, pe whiche might not be curid but by vertue of oure Lord that sende hym pat sikenes (RR).

17) For pe stone. Tak peiones mawes as mony as pat pou my3t gete, open hem $\&$ tak pe skynne next pe mete in pe mawe pe jnmest skynne. Make perof poudere $\&$ it wil be white. Tempre it with good ale $\&$ hit wil delyuere pe of pe stone (R3).

In these excerpts, personal pronouns serve the purpose of establishing differences in identity between text producers and text receivers, which is the case in (15) and (17), respectively. First person singular pronouns identify writers as authorities on the subject. The employment of this intrusive strategy helps to build their credibility and to achieve the reader's subsequent confidence in their medical knowledge. Second person pronouns are the means by which writers acknowledge reader presence, but they mark off their identities in the situational context, since these pronouns imply a distance between participants in the communicative exchange. While first person singular and second person pronouns seem to emphasise hierarchical relationships between author and audience, first person plural pronouns indicate solidarity including both writers and readers in the same religious community as is shown in (16). By using them, writers assume and make readers assume that they all share the same world of religious beliefs. Furthermore, inclusive oure constitutes a way of self mention as the writer is explicitly referred to in this expression as well as an engagement marker since it indicates the presence of an imagined audience. It stands in sharp contrast with $I$ and you pronouns because it aims at reducing distance between participants. 


\title{
5. Conclusion
}

I have analysed the occurrence of metadiscursive features in Middle English medical recipes in order to show their status as products of social engagement. In so doing I have followed Hyland's theoretical proposal for the classification of metadiscourse into two macrocategories, namely, interactive and interactional. The analysis has shown that Middle English medical texts do indeed contain many metadiscursive resources, being specially important the use of transition markers within the interactive dimension and engagement markers within the interactional one.

Transition markers serve the purpose of connecting processes and establishing clear relationships between stretches of discourse as a way of offering accurate indications for the preparation of the medicines. Consequently, their use can be said to be partly determined by the genre the texts belong to. Engagement markers, on their part, are mainly realised by the employment of pronouns, in particular, first person plural and second person. First person plural pronouns convey inclusive meanings by means of which both authors and audience are included in the same community, mainly religious. Second person pronouns are used to address readers directly as potential users of the remedies and to create social differentiation between text producers and text receivers.

Other metadiscursive features have been found as well such as code glosses, endophoric markers, evidentials and frame markers included in the interactive dimension. All of them are used by writers as discourse organisational devices which guide readers in the comprehension process, for instance, when further clarification of ideational material is offered; or when reference is made to other parts of the texts or to other sources of information. Self mention, boosters, hedges and attitude markers are also present in Middle English medical recipes with various functions, for instance, that of creating social differentiation between author and audience, and that of showing the writer's attitude towards propositional information and audience themselves.

\section{REFERENCES}

\author{
Alonso-Almeida, Francisco \\ 2008 "The pragmatics of and-conjunctives in Middle English medical recipes", Journal of \\ Historical Pragmatics 9/2: 171-199. \\ Barton, David \\ 1994 Literacy: An introduction to the ecology of written language. Oxford: Blackwell. \\ Barton, Ellen - Gail Stygall (eds.) \\ 2002 Discourse studies in composition. Cresskill, New Jersey: Hampton Press.
}


Bunton, David

1999 "The use of higher level metatext in Ph.D theses", English for Specific Purposes 18: 41-56.

Carroll, Ruth

1999 "The Middle English recipe as a text-type", Neuphilologische Mitteilungen 100/1: 2742.

Chafe, Wallace - Johanna Nichols (eds.)

1986 Evidentiality: The linguistic coding of epistemology. Norwood, New Jersey: Ablex.

Christie, Frances (ed.)

1984 Children writing: Reader. Geelong, Victoria: Deakin University Press.

Crismore, Avon - Rodney Farnsworth

1989 "Mr. Darwin and his readers: Exploring interpersonal discourse as a dimension of ethos", Rhetoric Review 8/1: 91-112.

Dafouz-Milne, Emma

2008 "The pragmatic role of textual and interpersonal metadiscourse markers in the construction and attainment of persuasion: A cross-linguistic study of newspaper discourse", Journal of Pragmatics 40: 95-113.

Eggins, Suzanne

1994 An introduction to systemic functional linguistics. London: Pinter.

Fernández-Moreno, Francisco - Miguel Fuster - Juan-José Calvo (eds.)

1994 English Historical Linguistics 1992: Papers from the $7^{\text {th }}$ International Conference on English Historical Linguistics. Amsterdam/Philadelphia: John Benjamins.

Fuertes-Olivera, Pedro - Marisol Velasco-Sacristán - Ascensión Arribas-Baño - Eva SamaniegoFernández

2001 "Persuasion and advertising English: Metadiscourse in slogans and headlines", Journal of Pragmatics 33: 1291-1307.

Gotti, Maurizio - Marina Dossena (eds.)

2001 Modality in specialized texts: Selected papers of the $1^{\text {st }}$ CERLIS Conference. Bern: Peter Lang.

Halliday, Michael

1985 Introduction to functional grammar. Edward Arnold: London.

Halliday, Michael - Ruqaiya Hasan

1976 Cohesion in English. London/New York: Longman.

Hyland, Ken

1998 Hedging in scientific research articles. Amsterdam/Philadelphia: John Benjamins.

1999 "Talking to students: Metadiscourse in introductory coursebooks", English for Specific Purposes 18/1: 3-26.

2000 "Hedges, boosters and lexical invisibility: Noticing modifiers in academic texts", Text 9/4: 179-197.

2005 Metadiscourse: Exploring interaction in writing. London: Continuum. Infantidou, Elly

2005 "The semantics and pragmatics of metadiscourse", Journal of Pragmatics 37: 13251353.

Kirk, John (ed.)

2000 Corpora Galore: Analyses and techniques in describing English. Amsterdam/Atlanta: Rodopi. 
Koutsantoni, Dimitra

2004 "Attitude, certainty and allusions to common knowledge inscientific research articles", Journal of English for Specific Purposes 3: 163-182.

Kuo, Chih-Hua

1999 "The use of personal pronouns: Role relationships in scientific journal articles", English for Specific Purposes 18/2: 121-138.

Levere, Trevor (ed.)

1982 Editing texts in the history of science and medicine. New York: Garland.

Martín-Martín, Pedro

2008 "The mitigation of scientific claims in research papers: A comparative study", International Journal of English Studies 8/2: 133-152.

Martin, James

1984 “Language, genre and register”, in: Frances Christie (ed.), 21-29.

Mithun, Marianne

1986 "Evidential diachrony in Northern Iroquoian", in: Wallace Chafe - Johanna Nichols (eds.), 89-112.

Swales, John

1990 Genre analysis. Cambridge: Cambridge University Press.

Taavitsainen, Irma

1994 "On the evolution of scientific writings from 1375 to 1675: Repertoire of emotive features”, in: Francisco Fernández-Moreno - Miguel Fuster - Juan-José Calvo (eds.), 329-342.

1999 "Metadiscursive practices and the evolution of Early English medical writing (13751550)", in: John Kirk (ed.), 191-207.

2001a "Evidentiality and scientific though-styles: English medical writing in Late Middle English and Early Modern English", in: Maurizio Gotti - Marina Dossena (eds.), 2152.

2001b "Middle English recipes: Genre characteristics, text type features and underlying traditions of writing", Journal of Historical Pragmatics 2/1: 85-113.

Taavitsainen, Irma - Päivi Pahta - Matti Mäkinen

2005 Middle English medical texts. Amsterdam: John Benjamins.

Thompson, Geoff - Puleng Thetela

1995 "The sound of one hand clapping: The management of interaction in written discourse", Text 15/1: 103-27.

Vande Kopple, William

1985 "Some exploratory discourse on metadiscourse", College Composition and Communication 36: 82-93.

2002 "Metadiscourse, discourse and issues in composition and rhetoric", in: Ellen Barton -

Voigts, Linda Gail Stygall (eds.), 91-113.

1982 "Editing Middle English medical texts: Needs and issues", in: Trevor Levere (ed.), 39-68.

Werlich, Egon

1976 A text grammar of English. Heidelberg. Quelle and Meyer.

Williams, Joseph

1981 Style: Ten lessons in clarity and grace. Glenview, Illinois: Scott, Foresman and Company. 